\title{
PUBLIC ENTERPRISES PRIVATIZATION,THE COSTS AND BENEFITS (ALBANIA CASE)
}

\author{
Erisa Musabelli \\ Lecturer Universiteti“A. Moisiu”, Durrës. Bussines Faculty.Albania \\ erisamusabelliu@hotmail.it,
}

\begin{abstract}
Privatization is the process that transfers the ownership of an enterprise, service agency or public asset to the private sector,from which ,essentisal positive.effects in the capital markets, financial assets and working groups, are expected. It affects the interests of different groups of the population and includes $80 \%$ of all the economic activities including the fields of energy, oil and gas, telecommunications, forests and waterways, roads and railways, ports and airports, rail and inland waterway. Over the past ten years a large amount of privatizations has been accomplished in Albania, indeed, many companies, institutions, societies, mines, which previously had been owned by the state, have now become private property. But does it affect the national economy in a positive or a negative way? Had the privatizations in our country been done in the right extent? in the process of economy's transformation, the emphasis is found in the structural reform, where one of the pillars that support these reforms is the process of privatization. This article will provide a detailed and an accurate situation of the development of this process in Albania, based on the assumption that "the privatization affects positively the state economy", what went right and what did not work properly, how can we take action in order to achieve an improvement? What are the costs and the benefits of the process of privatization in terms of macroeconomic, microeconomic and social aspects in Albania?
\end{abstract}

Keywords: privatizion,public enterprises, economy's transformation,public sector,costs,benefits,structural reform.

\section{Introduction}

In the process of economy's tranforming the emphasis is to structural reforms where one of the supporting pillars these reforms is process of privatization. Privatization is a political basis process that changes the role of the state in the economy but also society as a whole and this process in Albania is associated with social consequences such as high unemployment and moderate wages, and dismissal from work for older employees and unqualified, retraining etc..

\section{Hypothesis}

The hypothesis of this study is:

Privatization, how does it affects in a country's economy, the costs and benefits associated with. "

\section{Argument}

Privatization has not been the same in all countries, each country has its specifics in this field, every country has its laws and regulations to implement the privatization that may be different from one country to another but this is reflected in the joint results that must be, increased efficiency and productivity of enterprises through privatization, increased public investment from the revenues derived from privatization etj.Privatization is a process that is closely related to the economy and has great influence on it. 
Tabela1 Framework for assessing the reform of public enterprises

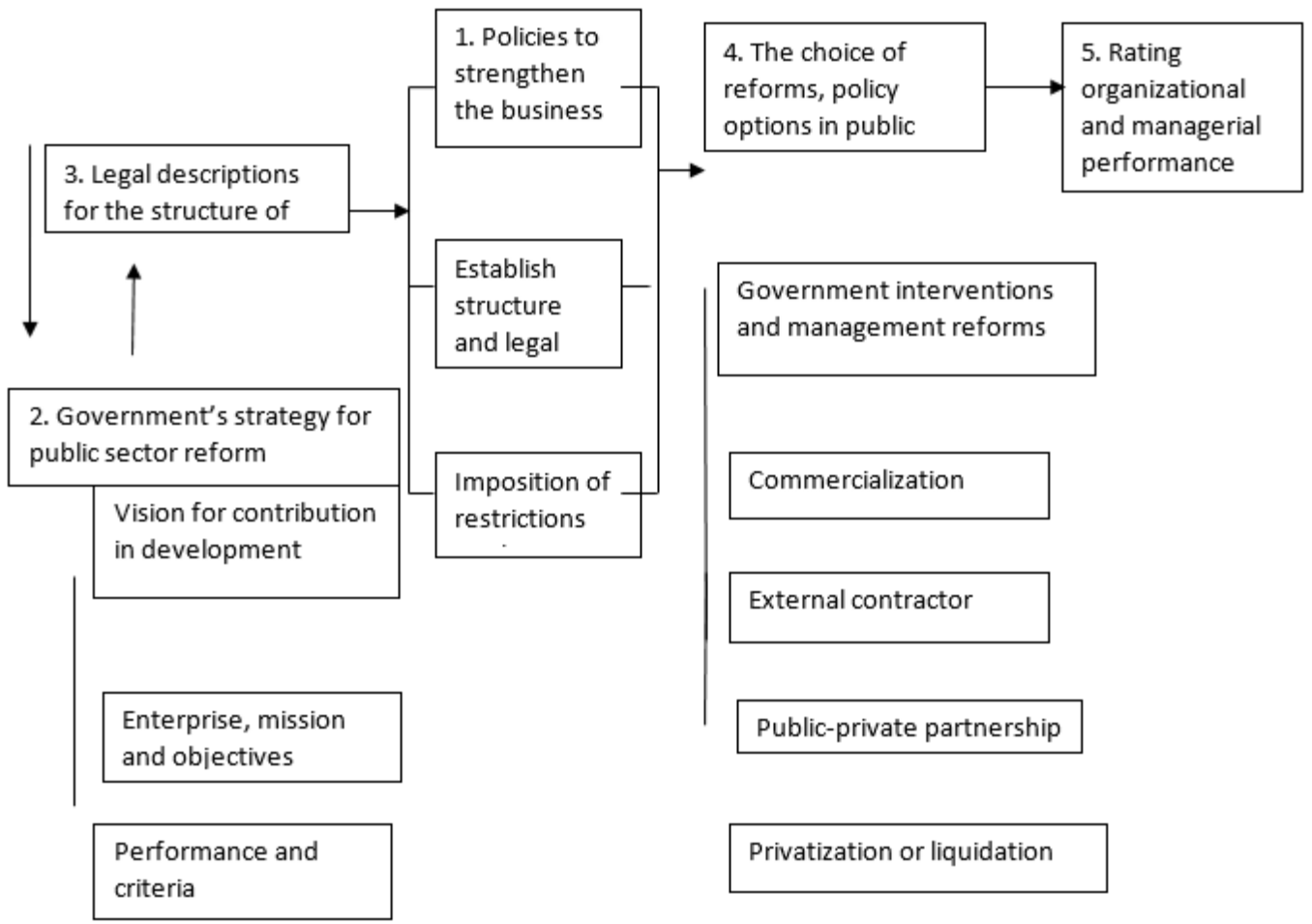

Experience has shown that governments should take the following actions to effectively manage privatization.

Development of a strategic management plan for privatization.

Establish an effective privatization agency.

To choose appropriate methods of privatization

To develop clearly and transparent way, privatization procedures

Application as appropriate methods of assessment and evaluation

Establish effective financial structures for participation in the privatization of the private sector.

Establish an effective system of supervision and regulation of the government especially for natural monopolies.

To assist in strengthening the capacity of private sector management

Establish measures for the protection of employment for current government workers in organizations to be privatized.

\section{Method and Participants}

This work is carried out according to a study in public and private institutions in Albania, which has involved a certain number of individuals who have provided relevant information regarding to the topic.Participants are leaders in these institutions who were ready to contribute in this direction. 


\section{Materials}

All constructs were measured using as instruments, sources obtained from existing literature in appropriate institutions, revising and bringing them adapting to study.

\section{Procedure}

The direct meeting with the directors of these institutions to gather information about what happens in public and private enterprises.Received informacion at their websites and compare for the changes associated with their benefits and costs

\section{Results}

The aim of this paper is to be familiar with the process of privatization and it's effects in economy.

\section{Objectives}

Description of the privatization process

- Identify the effects of this process on economy

- Introduction to the progress of privatization in our country

- efficiency, costs, economic and social benefits.

- Drawing conclusions and recommendations.

As a conclusion based on the study we can say that,from the experience of the privatization process in Albania, this process would be beneficial for the economy of this country.

\section{Findings in the privatization process}

Economic reform process began in July 1992 when the government program was supported by the agreement "stand by" with the International Monetary Fund. Based on international expertise, the process of turning public property into private was conducted on the basis of a clear program and higher rates.Criterias and methods of achieving this goal had been improving and enriched continuously. in Albania the transfer of the right of ownership is widely used in the privatization process during the period 1991-2000. The privatization of the economy, as a process that changed the appearance of the Albanian society took two stages and concrete.

1.The first phase, privatization of small and medium enterprises (SME).

Small enterprises considered all those who had the money value equal to no more than $\$ 100,000$, or no more than 50 workers.

Medium enterprise considered all those who had the money value equal to no more than $\$ 500,000$, or less than 300 workers

2. The second phase, privatization of large enterprises.

Large enterprises were considered all that had value in money equal to about $\$ 500,000$, or about 300 workers

Findings on the benefits and costs of the privatization process

Now days more mixed organizational forms of public enterprises that combine centralized management of a number of decisions and proper response to market signals are receiving a significant advantage

In these conditions will be a part of a public enterprise economically optimal solution?

Our response is based on benefit-cost analysis on this two moments.

1 - Benefits may result from government intervention in cases of market failure or in cases where the behavior of private producers in terms of profit maximization becomes incompatible with the interests of maximizing Social Welfare. 
2-Cost will have in cases of organizational failure associated with different specific mechanisms A special tool institutional like public company can achieve a target avoidance behavior in relation to private enterprise, as pricing based on marginal costs instead of price based on marginal income in a natural monopoly situation, but at the same time it can produce undesired deviations, lets say, inefficiencies costs that should be compared with the costs associated with other mechanisms of interference in private interprise

\section{Microeconomic Benefits}

Privatization brings some benefits for state enterprises:

1)Increased efficiency and cost reduction is the removal of excess employees from those companies, which contributes in this direction and also private decision encourages employees to be motivated to defend their place of work.

2) Increased investment

The pass of interprise from situation with loss and lack of investment resources towards creating opportunities for investment and expansion of domestic and foreign shareholders.

3) The new form of management

Have increased motivation which increases even further by the presence of foreign investors, but also by the lack of political pressures in the decision making of managers

4) Technology and Training

New investment means the most advanced technology accompanied with a full training employees to use this technology.

\section{Macroeconomic Benefits}

Privatization brings macroeconomic benefits such as:

\section{Fiscal Stability}

State finances could be improved in two ways:

By spending cuts to cover the subsidy and losses of enterprises, thus reducing inflation pressure and destabilizing effects on the one hand and the state can receive income from the sale of state enterprises on the other hand

2. The development of the capital market

In countries without a developed capital market is difficult to sell shares to local and foreign investors and as a result the process of privatization can not succeed, but some countries have used privatization to promote capital market development.

\section{Increased competition}

Through privatization local products enter in new markets, and it promotes competition and increased efficiency of production of services. But on the other and the loss of state subsidy should be done gradually to ensure that the enterprise has a capable structure for a competition in markets where will enter.

\section{Attracting Foreign Investment}

Privatization stabilizes fiscal and economy situation of the country the for a longer term. A stable macroeconomic environment encourages investment, especially foreign investment, bringing benefits that are important to achieving the country's future.

\section{Costs of Privatization}

The lack of a strategy (short, medium, long) would ensure harmonization of economic objectives, social and financial micro and macro level, the supply-demand balance in privatization with final aiming for due process efficient

Massive privatization program through issuance of bonds resulted in a political-propaganda bluff with difficult bill for repairs. According to statistics of the AKP, in 2005 in massive, small and medium privatization, are used 10.2 billion ALL privatization shares and 4.6 billion ALL privatization, therefore a total amount of 14.8 billion ALL and from these, are used only $16.3 \%$ 
of the amount of privatization shares while were privatized 107 joint stock company and many of small and medium enterprises.

Speed of performing the process of privatization before and not parallel with the privatization of the banking system created a number of issues for young entrepreneurs financing.

Problems in relation to the former owners of the land. Existence of the Law No. 7698 dated .0415 .1993 "for restitution and compensation of property to former owners' and decisions on the basis of which carried out the privatization process and activity of the commissions for return and compensation of properties was not rare in contradiction with each other.

Fragmentation of former state enterprises and their piecemeal sales, have made to be out of focus of private entities, causing the state to pay thousands of officer and guard without any interest.

Failure of financial guarantees and customer management skills buyer, has made a piece of manufacturing unit to fall in the unsafe "hands"

Selling unconditionally development has ensured treated equally, manufacturing facilities as well as those non-productive causing consequences in economy's development.

Revenues from privatization in years

\begin{tabular}{|c|c|c|c|c|c|c|c|c|c|c|c|}
\hline & 1994 & $\begin{array}{l}199 \\
5\end{array}$ & $\begin{array}{l}199 \\
6\end{array}$ & $\begin{array}{l}1999 \\
7\end{array}$ & 1998 & 1999 & 2000 & 2001 & $\begin{array}{l}200 \\
2\end{array}$ & 2003 & 2004 \\
\hline $\begin{array}{l}\text { Actual income } \\
\text { from privatization }\end{array}$ & $\begin{array}{l}2,35 \\
8\end{array}$ & 309 & 616 & 910 & 133 & 906 & 8,932 & $\begin{array}{l}12,68 \\
6\end{array}$ & 485 & 899 & $\begin{array}{l}14,35 \\
6\end{array}$ \\
\hline & & & $\begin{array}{l}200 \\
5\end{array}$ & 2006 & 2007 & 2008 & 2009 & 2010 & $\begin{array}{l}201 \\
1\end{array}$ & 2012 & 2013 \\
\hline & & & 887 & 1,972 & $\begin{array}{l}13,24 \\
6\end{array}$ & $\begin{array}{l}5,53 \\
8\end{array}$ & $\begin{array}{l}25,13 \\
8\end{array}$ & 411 & 438 & 888 & N/A \\
\hline
\end{tabular}

\section{Actual income from privatization}

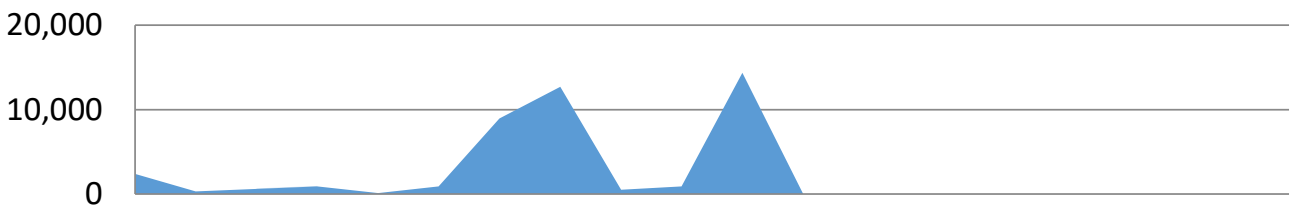

1994199519969997998199900020010020032004

\section{Successful privatizations in years}

AMC Albanian Mobile Communication: is a telecommunications company offering since 1995 this type of service. AMC was sold at an international auction, supervisor from BERZH in which the he largest offer was presented by Consortium great Consmote (GREECE) and Telenor (Norway).Today AMC counts 600,000 subscribers, investments made in maintenance, technology, network expansion exceeding 200 million euro. It's network covers $85 \%$ of the territory and $90 \%$ of the populationand it has 300 employees

Seament Albania L.T.C in March 1997 Albania Cement Company bought 70\% of shares in cement factory in Fushe Kruja and in the end of 1999 he bought a share in Elbasan Cement Factory. in July 2000m these factories were privatized and over the years they have been refurbished with a contemporary technology by increasing production capacity. 
Vodafone Albania :Tender for the second GSM operator mobility was issued in September 2000.On February 2001 Vodafone Uk was elected as winner with $51 \%$ of the shares and Panafon Greece with $49 \%$, offering 38.1 million USD. Vodafone network covers about $75 \%$ of the territory and $85 \%$ of the population, 300 million euro investment

Kürüm International Ltd: Turkish company which operates in the metallurgical industry. This company operates in Turkey and Kosovo, numbering about 530 employees, it produces only for the Albanian market but include projects which implies the possibility of exports and increase production.

National Commercial Bank: Privatization was completed in October 2000. It was sold to a consortium of investors Kentbank Turkey, IFC, EBRD for an amount of USD 10 million. This bank has increased with 40 branches and agencies in 30 cities.

Savings Bank: 2003 was a successful year for FDI in Albania. Great achievement of this the privatization was ,Savings Bank of Austrian Bank ,Raiffeisen Bank with a bid of USD 126 million. This bank has entered strongly in the financial market by increasing competition, increasing the number of services and being widespread in Albania.

Darfo Albania: The ferrochrome production is taken for a concession period of 30 years by an Italian company.

Airport Mother Teresa: has given with concession for a period of 20 years to consortium "AIRPOTPARTNERS". Signing of the contract with the American giant Lockheed-Martin for an investment of 32 million USD for installation of air traffic control that was achieved during 2004.

\section{Revenues from privatization (million ALL)}

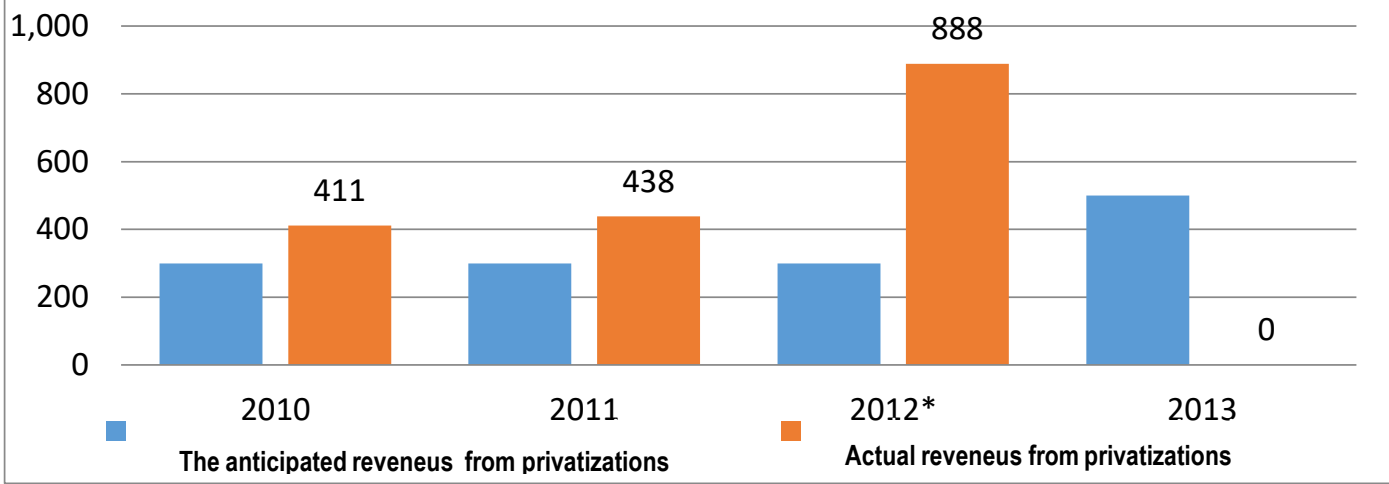

\section{Are all privatizations successful?}

Not all are successful privatizations, as an example of the failure of privatization process can mention privatization of CEZ Distribution which not only brings no benefit to the economy but has damaged it and the customer.

Inability of CEZ not deflate.Energy Regulator Office suggests in the report, if the losses would be at a low level, then the Albanian citizens will pay a low price energy.Such losses are recognized by technical and non-technical reasons, consequently not good management of these causes leads to inability to cover costs.

CEZ performance is away from objectives. Withstanding that there was an improvement in the level of collections compared to 2009 , the rate of CEZ company performance is still far from adequate objectives. Greater specific level of efficiency in energy consumption is concentrated in the Tirana, Fier, Durres and Shkoder aria.

Method of billing was not correct from the part of CEZ Distribution. November,December 2012 have been recorded around 20,000 bills, issued arbitrarily and contrary to law code power measurement.

The privatization of CEZ has no change in well management,company and it is away from objectives

In 2009, 80 complaints were registered (50 households, 25 non-family, 5 licensed facilities) while in 2010 these complaints increased by 350 ,but we are not including here consultation and complaints made by electronic mail and phone.

Revenues generated by CEZ for 2008-2011(in ALL) 


\begin{tabular}{|c|c|c|c|c|}
\hline $\begin{array}{l}\text { ISSN 2411- } \\
\text { ISSN 2312- }\end{array}$ & & $\begin{array}{l}\text { ropean Journal of } \\
\text { Education and }\end{array}$ & iences & $\begin{array}{l}\text { May-August } 2014 \\
\text { Volume 1, Issue } 1\end{array}$ \\
\hline & 2008 & 2009 & 2010 & 2011 \\
\hline Reveneus & 259521739 & 268478261 & 349347826 & 352253623 \\
\hline Costs & 320043478 & 400413043 & 364000000 & 430537089 \\
\hline Losses & -60521739 & -131934783 & -14652174 & -78203466 \\
\hline
\end{tabular}

\section{Conclusions and recommendations}

\section{Conclusions}

Privation is only one element of the reforming process of the whole Albanian society.

Public sector enterprises are more adaptable to political objectives rather than to economic objectives compatible to the logic of free market.

The absence of profit motivation that was alimented from the absence of competition caused the inefficiency of state owned enterprises. Those enterprise did not focus on producing quality product and services. They were also obliged to employ over capacity.

The process of privatization was also accompagnied by high unemployement rates.

Public sector enterprises did not have anymore subsidies.

Prices were set up artificially. in a centralized economy prices were set up by the governement.

A consolidated macroecomic environment attracs foreign investement that are essential for future economic growth.

Albania has been lacking of a planned privatization strategy. Massive privatization was not successful, the structure of the ownership of the companies was not transparent and effective.

The social cost of privization was manifested moslty through unemployement, wage inqualities.

A new kind of "enterpreneurs" and "new bourgeoisie" appeared but not from market competition, in most of the cases they were connected to corruptive affairs

\section{Recommendations}

A concrete and effective strategy is needed. Deadlines in implementation should be respected and it should be followed by post-program mechanisms that can lead to a further attraction of foreign investment.

Political stabily should be achieved in order to allow public sector enterprises to focus more in long term objectives rather than in short term objectives.

Bureaucracy in public sector decision making should be elemined gradualy consequently public sector enterprises should be more reactive towards market challenges.

State monopolies should be eleminated in these sectors where it is possible. Barriers and tariffs should be abolished not only to allow business expansion and to make public sector enterprises more competitve.

Macroeconomic stability impacts growth through boosting foreign investment.

The procedure of estimation of the value of the assets that are going to be privatized should be improved. 
Transparency should be insured through fighting corruption.

The propriety of the employee should be transferred because it is on of the most transparent transferring methods that does not allow corruption.

\section{References}

[1] (2010) 'Good Government Means Different Things in Different Countries', Governance, 23:1, pp. 7-35.

[2] (eds.) (2006) Public Service Performance: Perspectives on Measurement and Management, Cambridge, Cambridge University Press.

[3] Barbier, J.-C. and Simonin, B. (1997) ‘European Social Programmes: Can Evaluation of Implementation Increase the Appropriateness of Findings?', Evaluation, 3:4, October, pp. 391-407

[4] Denis A.RONDINELI (Can Public Enterprises Contribuite To Development?)

[5] Economy, Trade and Energy Ministry

[6] -Eymeri-Douzans, J-M. (2010) 'Introduction: Administrative Reforms and Mergers in Europe-Research Questions and Empirical Challenges', International Review of Administrative Sciences, 76:3, pp. 395-406.

[7] http://www.akp.gov.al

[8] http://www.instat.gov.al/al/home.aspx

[9] http://www.mete.gov.al/

[10] http://www.minfin.gov.al/minfin/ministria

[11] Matreials from Archives of the National Privatization Agency

[12] McGuire, M. (2001) 'Big Questions in Public Network Management Research', Journal of Public Administration Research and Theory, 11:3, pp. 295-326

[13] P. (2004) 'Joined-Up Government in theWestern World in Comparative Perspective: A Preliminary Literature Review and Exploration', Journal of Public Administration Research and Theory, 14:1, pp. 103-38

[14] Remzi KECO,llir KAPAJ Public Administration 